\title{
En recuerdo de José María Medianero
}

José María Medianero (Sevilla, 1956-2005) fue Doctor en Historia de Arte y profesor titular del Departamento de esta especialidad en la Universidad de Sevilla. Tuvo un curriculum académico sobresaliente en el que destacan el Premio Extraordinario de Licenciatura, el Premio del Ayuntamiento de Sevilla al mejor expediente académico y el Premio Nacional Manuel Corchado de Investigaciones Histórico-Arqueológicas.

Por su compromiso con la cultura andaluza optó inicialmente por una alternativa profesional alejada del mundo académico: fue coordinador de la sección de Arte del ambicioso proyecto editorial de la Gran Enciclopedia de Andalucía, trabajó para la administración autonómica en la preservación del patrimonio artístico de nuestra Comunidad y formó parte activa de asociaciones preocupadas por la situación del patrimonio como el Centro de Investigación del Patrimonio Artístico Andaluz y del Observatorio Andaluz para la Economía de la Cultura y el Desarrollo.

Sin embargo, la investigación y la docencia constituían su vocación más querida, y volvió al mundo académico. Su labor investigadora entonces se relacionó fundamentalmente con aspectos variados del arte medieval, contando con numerosas publicaciones. Persona inquieta abordó, por tanto, temas muy variados. Fruto de su relación de cariño con la Sierra de Aracena fue su incursión en el estudio de las manifestaciones artísticas emanadas de la cultura popular y, en este sentido, ha sido uno de los primeros historiadores del arte andaluces que se han dedicado a este ámbito.

Su presencia ha sido notable, con ponencias y comunicaciones, en las Jornadas del Patrimonio de la Sierra de Huelva, participaciones que luego se han concretado en los libros Empedrados decorativos de la Sierra de Aracena (1997), y Fuentes y lavaderos en la Sierra de Huelva (2003). Este último constituye un estudio sistemático de todas las obras vinculadas con la arquitectura popular, desde una metodología fundamentalmente histórico-artística, sin renunciar a realizar aportaciones de interés para otras disciplinas.

El impacto de su estudio supuso un punto de inflexión en la lenta pero inexorable destrucción de un legado, aún vivo pero olvidado, y provocó el cambio de aptitud de algunas autoridades locales, como sucedió con la lectura de su ponencia en las Jornadas del Patrimonio celebradas en Cortelazor en 1998, pues, tras ella, la alcaldesa se comprometió públicamente a sustituir una desafortunada fuente decorativa recién implantada en la plaza principal de la población-, y restaurar el viejo lavadero.

Respetado por sus compañeros y apreciado por sus alumnos, su repentina y dolorosa desaparición, en un momento de plenitud creativa y personal, ha supuesto un duro e injusto golpe para su entorno familiar y para sus amigos, en los que ha dejado una profunda e inolvidable huella.

Antonio Fajardo de la Fuente

Pedro Suárez Rodríguez 